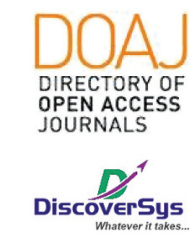

Published by DiscoverSys

\section{Validitas nilai CA 19-9 praoperatif dalam memprediksi resektabilitas pada kejadian karsinoma pankreas}

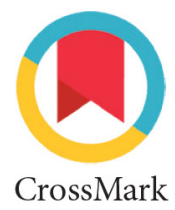

Wiguna, KA., ${ }^{1 *}$ Sudartana, K., ${ }^{1}$ Golden, N. ${ }^{1}$
'Departemen Ilmu Bedah, Fakultas Kedokteran, Universitas Udayana

\section{*Corresponding:}

Wiguna, KA.

Departemen IImu Bedah, Fakultas Kedokteran, Universitas Udayana kadek.adi.wiguna@gmail.com

Received: 2018-10-31 Accepted: 2018-1-30 Published: 2019-4-1

\title{
ABSTRAK
}

Pendahuluan: Karsinoma pankreas adalah penyakit dengan median survival rate yang rendah dengan angka resektabilitas yang juga rendah. pasien dengan stadium lanjut hanya kurang dari 10 $\%$ dapat direseksi dengan kriteria margin nol setelah sebelumnya dinyatakan dapat direseksi dari pemeriksaan CT scan. Tujuan dari penelitian ini untuk mengetahui validitas dari CA 19-9 sebagai prediktor derajat invasif karsinoma pankreas.

Metode: Rancangan penelitian ini adalah kasus kontrol dengan retrospektif, menelusuri kebelakang data data pasien di rekam medik di RSUP Sanglah Denpasar mulai agustus 2015 sampai agustus 2017. Didapatkan 18 pasien yang memenuhi kriteria inklusi.
Hasil: rata - rata responden dengan karsinoma pankreas berumur 52 tahun, kanker pankreas di nyatakan unresectable berdasarkan analisis curva Receiver Operating Characteristic (ROC) AUC (Area Under (urve) sebesar 83,8\% (CI 95\%: 54,4\% - 100\%). Titik potong dari kurva AUC kadar CA 19-9 yaitu 126,76 dengan sensitifitas sebesar 76, 9 \% dan spesifitas $80 \%$. Secara statistik didapatkan CA 19-9 valid sebagai penentu unresektabilitas dengan sensitivitas sebesar 76,9\%.

Kesimpulan: CA 19-9 merupakan tumor marker yang dapat memprediksi derajat invasi suatu kanker pankreas sehingga diharapkan tindakan lebih tepat dapat segera diambil bila kita mengetahui nilai dari tumor marker ini.

Kata Kunci: CA19-9, kanker pankreas, resektabilitas

Cite Pasal ini: Wiguna, KA., Sudartana, K., Golden, N. 2018. Validitas nilai CA 19-9 praoperatif dalam memprediksi resektabilitas pada kejadian karsinoma pankreas. Intisari Sains Medis 10 (1): 6-9. D0I: 10.1556/ism.v10i1.340

\section{PENDAHULUAN}

Kanker pankreas merupakan penyebab kematian ke-4 bagi laki-laki dan ke-5 bagi wanita, dan pada $80 \%$ penderita mengenai usia 60 - 80 tahun. Angka kematian kankers pankreas masih sangat tinggi, yakni 98 \% pasien akan meninggal. ${ }^{1,2}$ Sebagian besar pasien meninggal dalam waktu 1 tahun setelah diagnosis penyakit. Secara keseluruhan, angka harapan hidup 1 tahun sekitar 12\%, 5 tahun sekitar $0,4 \%-4 \% .^{3}$

Pada umumnya pasien dengan karsinoma pankreas datang dengan stadium lanjut. Pemeriksaan CT scan untuk resektabilitas dinyatakan efektif bila di lakukan 6 bulan sebelum diagnose klinik ditegakkan, namun dalam stadium lanjut hanya kurang dari $10 \%$ dapat direseksi dengan kriteria margin nol setelah sebelumnya dinyatakan dapat direseksi dari pemeriksaan CT scan, sehingga menunjukan bahwa kanker pankreas memiliki tingkat harapan hidup yang rendah. Hal ini juga dinyatakan bahwa hanya $4 \%$ pasien memiliki survival rate 5 tahun. Empat puluh lima persen penderita baru bersifat "local advance" yang artinya "unresectable" dengan atau tanpa metastis jauh. ${ }^{4}$

Cancer antigen 19-9 (CA 19-9) merupakan suatu antigen karbohidrat, ditemukan sebagai suatu antibodi monoklonal IgG tikus yang muncul sebagai reaksi terhadap sel karsinoma kolon manusia oleh Koprowsky dan kolega pada tahun 1979. Cancer antigen 19-9 dideteksi awalnya pada jaringan kolorektal tetapi ditemukan lebih banyak terdistribusi pada pankreas normal, lambung, dan epitel biliar, dan juga pada serum pasien dengan karsinoma pankreas. ${ }^{5,6}$ CA 19-9 merupakan tumor marker dengan range sensivitas dari 69\% sampai 93 $\%$ dan rentangan spesifisitas dari 78\% sampai 98\% untuk mendeteksi karsinoma pankreas.

Studi oleh Mehmet Killic et all. 2006 di dapatkan kadar titik potong optimum kadar CA 19-9 yaitu 256,4 U/dl yang mengindikasikan kanker pankreas di nyatakan unresectable berdasarkan analisis kurva Receiver Operating Characteristic (ROC) walaupun pada pemeriksaan CT scan di nyatakan sebaliknya. Sehingga, peneliti ingin mengetahui validitas nilai CA 19-9 untuk memprediksi dilakukan resektabilitaspada pasien karsinoma pankreas. ${ }^{3}$

\section{METODE}

Penelitian ini dilaksanakan di Poliklinik Digestif RSUP Sanglah Denpasar dengan mengambil data pasien dari Instalasi Rekam Medik RSUP Sanglah Denpasar,mulai bulan agustus 2015 sampai agustus 2017. Desain penelitian menggunakan 
observasional retrospektif analitik, dengan rancangan penelitian yang digunakan adalah kasus kontrol. Kelompok kasus adalah pasien pasien karsinoma pankreas yang tidak dapat direseksi, sedangkan kelompok kontrol yaitu karsinoma pankreas yang dapat direseksi (Gambar 1).

\section{Populasi dan sampel}

Populasi terjangkau adalah semua pasien dengan karsinoma pankreas yang berobat di RSUP Sanglah Denpasar selama 5 tahun. Sampel yang dipilih dengan teknik berurutan (consecutive sampling) dengan perhitungan jumlah sampel minimal masing masing kelompok yaitu 13 sampel. Kriteria inklusi yaitu penderita yang menderita kanker pankreas yang berobat ke RSUP Sanglah sejak 1 Januari 2011 sampai 31 Desember 2016 dan mendapatkan penatalaksanaan sesuai prosedur standar operasional, sedangkan kriteria eksklusi yaitu data rekam medik tidak lengkap dan pasien yang tidak di periksa CA 19-9, tidak dilakukan imaging abdomen, atau tidak dilakukan operasi atau salah satu diantaranya. Penelitian ini telah mendapatkan izin etik dari Komisi Etik Fakultas Kedokteran Universitas Udayana dengan nomor 2017.02.1.1039.

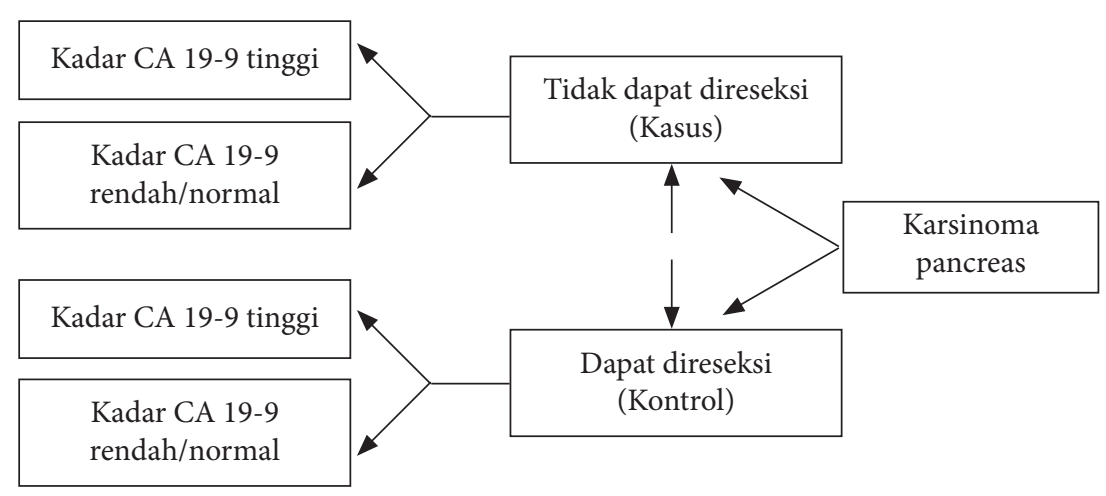

Gambar 1. Skema rancangan penelitian

Tabel 1. Tabulasi Umur, Jenis Kelamin, dan Kadar CA 19-9 terhadap Tindakan

\begin{tabular}{|c|c|c|c|c|c|}
\hline \multirow{2}{*}{ Variable } & \multicolumn{2}{|c|}{ Tindakan } & \multirow[b]{2}{*}{ OR } & \multirow[b]{2}{*}{$\mathrm{Cl} 95 \%$} & \multirow{2}{*}{ p-value } \\
\hline & Non Resectable & Resectable & & & \\
\hline \multicolumn{6}{|l|}{ Umur, } \\
\hline$>60$ tahun & $3(60 \%)$ & $2(40 \%)$ & 0,450 & $0,050-4,085$ & 0,473 \\
\hline$\leq 60$ tahun & $10(76,9 \%)$ & $3(23,1 \%)$ & & & \\
\hline \multicolumn{6}{|l|}{ Jenis kelamin } \\
\hline Laki-laki & $10(71,4 \%)$ & $4(28,6 \%)$ & 0,833 & $0,066-10,597$ & 0,888 \\
\hline Perempuan & $3(75 \%)$ & $1(25 \%)$ & & & \\
\hline \multicolumn{6}{|l|}{ Kadar CA 19-9 } \\
\hline$>126,76$ & $10(90,9 \%)$ & $1(9,1 \%)$ & 13,33 & $1,048-169,55$ & 0,026 \\
\hline$\leq 126,76$ & $3(42,8 \%)$ & $4(57,2 \%)$ & & & \\
\hline
\end{tabular}

Analisis statistik deskriptif akan ditampilkan menggunakan tabulasi silang, sehingga dapat dinilai dikomparabilitas subyek antara kelompok kontrol dengan kasus apakah sudah komparabel atau belum. Analisis kurva ROC untuk mencari titik potong terbaik dari CA 19-9. Analisis multivariat untuk mengetahui kemampuan atau faktor prediktor murni dari masing-masing variabel bebas terhadap variabel tergantung, setelah memperhitungkan variabel bebas lainnya dengan menggunakan Regresi Logistik Kondisional. Nilai signifikan $\mathrm{p}<0.05$.

\section{HASIL PENELITIAN}

\section{Umur, Jenis Kelamin, dan Kadar CA 19-9 terhadap Tindakan}

Variabel kadar CA 19-9 menunjukan hubungan yang signifikan terhadap variabel tindakan (OR: 13,33; CI95\%: 1,048-169,55; p,0.05), sehingga kadar CA 19-9 merupakan faktor prediktif dalam menentukan tindakan. Variabel umur dan jenis kelamin tidak menunjukan hubungan yang signifikan dengan variabel tindakan (Tabel 1).

\section{Keakuratan CA 19-9 dalam Memprediksi Resectabilitas}

Nilai AUC CA 19-9 didapatkan sebesar 83,8\% (CI95\%: 54,4\% - 100\%) dengan cut of point kadar CA 19-9 yaitu 126,76 dengan sensitifitas sebesar $76,9 \%$ dan spesifitas $80 \%$ (Tabel 2).

\section{Hubungan Kadar CA 19-9 Terhadap Resektabilitas Dikontrol Dengan Variable Umur Dan Jenis Kelamin}

Kadar CA19-9 didapatkan dengan nilai $\operatorname{Exp}(\mathrm{B})$ 13,33 (CI95\%: 1.048-169.557) dengan p-value 0,046 artinya kadar CA 19-9 memiliki peluang 13,33 untuk tidak dilakukan reseksi pada kasus karsinoma pankreas setelah dikontrol dengan variabel umur dan jenis kelamin (Tabel 3).

\section{PEMBAHASAN}

Usia insiden rata rata pasien karsinoma pakreas adalah usia 52 tahun yang umumnya lebih muda di bandingkan usia pasien di negara - negara barat pada penelitian McCulloch, Peter 2005, Lall CG 2007 berkisar antara 60 sampai 80 tahun., ${ }^{4,6,7}$ Dengan insiden pasien yang memenuhi kriteria inklusi laki - laki 14 orang $(77,8 \%)$ lebih banyak di banding perempuan 4 pasien $(22,2 \%)$ sesuai dengan insiden pada penelitian penelitian sebelumnya di mana umumnya laki - laki lebih banyak dibandingkan perempuan. Kadar CA19-9 > 126,76 yang nonrecectable sebanyak $10(90,9 \%)$ dan yang dilakukan resectable sebanyak $1(9,1 \%)$ sedangkan 
Tabel 2. Kemampuan CA 19-9 Memprediksi Resectabilitas

\begin{tabular}{cccccc}
\hline Variable & $\begin{array}{c}\text { Nilai } \\
\text { AUC }\end{array}$ & Sensitifitas & Spesifitas & Cl 95\% & p-value \\
\hline Kadar CA19-9 & $83,8 \%$ & $76,9 \%$ & $80 \%$ & $57,4 \%-100 \%$ & 0,03 \\
\hline
\end{tabular}

Tabel 3. Hubungan Kadar CA 19-9 Terhadap Resektabilitas Dikontrol dengan Umur dan Jenis Kelamin

\begin{tabular}{lccc}
\hline \multicolumn{1}{c}{ Variable } & Ajusted Odd Ratio & Cl 95\% & p-value \\
\hline Step $1^{\text {a }}$ & & & \\
Umur & 0.737 & $0.049-11.014$ & 0.825 \\
Sex & 0.470 & $0.023-9.501$ & 0.623 \\
Kadar CA191 & 13.835 & $0.958-199.823$ & 0.054 \\
Constant & 0.030 & - & 0.386 \\
Step 2 & & & \\
Sex & 0,496 & $.025-9.645$ & 0,643 \\
Kadar CA191 & 14,806 & $1.081-202.771$ & 0,044 \\
Constant & 0,015 & - & 0,112 \\
Step 3 & & & \\
Kadar CA191 & 13,333 & $1.048-169.557$ & 0,046 \\
Constant & 0.008 & - & 0,028 \\
\hline
\end{tabular}

kadar CA $19-9=126,76$ yang nonrecectable sebanyak 3(42, 8\%) dan yang dilakukan resectable sebanyak $4(57,2 \%)$.

Menurut penelitian Vogt et al. (2000) CA 19-9 merupakan tumor marker yang di nyatakan berpengaruh pada karsinoma pankreas dengan range sensivitas dari 69\% sampai $93 \%$ dan range spesifisitas dari $78 \%$ sampai $98 \% .^{5}$ Pada penelitian ini pasien yang menderita karsinoma pankreas juga memiliki kadar CA 19-9 yang lebih tinggi dibandingkan kadar normal. Penelitian Mehmet Killic et all. 2006 di dapatkan kadar optimum cut off kadar CA 19-9 yaitu 256,4 U/dl yang mengindikasikan kanker pankreas dinyatakan unresectable berdasarkan analisis kurva Receiver Operating Characteristic (ROC) walaupun pada pemeriksaan CT scan di nyatakan sebaliknya. Nilai AUC pada penelitian ini sebesar 83,8\% (CI 95\%: $54,4 \%$ - 100, \%) secara statistic nilai AUC sebesar $83,8 \%$ tergolong tinggi. Titik potong dari kurva AUC cut of point kadar CA 19-9 yaitu 126,76 dengan sensitifitas sebesar 76, $9 \%$ dan spesifitas 80 $\%$. $3,8,9$

\section{Sensitifitas}

Nilai sensitifitas CA19-9 dalam memprediksi karsinoma pankreas yang tidak dapat direseksi adalah sebesar 76,9\% pada kadar CA 19-9 lebih dari 126,76 U/DL. Pada 10 pasien ditemukan CA 19-9 yang tinggi di atas cut off point (true positive) sedangkan 3 pasien dengan CA 19-9 yang rendah di bawah titik potong tidak dapat dilakukan reseksi pada karsinomanya. Nilai CA19-9 pada 3 pasien false negative yang tidak dapat direseksi ini di bawah 126,76U/dl karena pada durante operasi didapatkan invasi karsinoma pankreas ke organ organ sekitar dan ke pembuluh darah cabang utama dengan hasil patologi anatomi adenokarsinoma dan pada satu pasien dengan acinar cell carcinoma.

Kanker yang letaknya di korpus dan kaudal akan lebih sering mengalami metastasis ke hati, bisa juga ke limpa. ${ }^{10}$ Nilai sensitifitas ini direkomendasikan untuk tujuan pengambilan keputusan terapi dalam memprediksi unresectable pada pasien karsinoma pankreas, sehingga diharapkan dapat membantu klinisi mempercepat pemberian terapi. ${ }^{11}$

\section{Spesifisitas}

Nilai spesifisitas CA 19-9 dalam memprediksi unresectable pada pasien karsinoma pankreas sebesar $80 \%$. Nilai spesifisitas ini didapatkan karena dari 5 pasien yang dilakukan reseksi, 4 pasien dengan CA 19-9 di bawah cut off 126,76 $\mathrm{U} / \mathrm{dl}$ (true negative) sedangkan 1 pasien dengan CA 19-9 di atas 126,76U/DL (false positive). Satu pasien false positive dengan CA 19-9 di atas cut off $126,76 \mathrm{U} / \mathrm{dl}$ ini didapatkan karena pada 1 pasien false positive yang dapat direseksi lebih dari 126,76U/dl di lakukan operasi segera setelah dicurigai adanya suatu karsinoma pankreas sebelum diagnosis klinik ditegakkan sesuai dengan penelitian Suresh.T.2007. ${ }^{12,13}$ Jenis pathologi anatomi pada pasien yang dapat direseksi dengan jenis mucinous adenokarsinoma. Nilai spesifisitas direkomendasikan untuk pengambilan keputusan reseksi pada pasien karsinoma pankreas, sehingga diharapkan dapat membantu pengambilan keputusan penatalaksanaan reseksi ataupun unreseksi pada pasien tersebut. ${ }^{11,14,15}$

\section{KESIMPULAN}

Hasil uji diagnostik validitas CA 19-9 dalam memprediksi unresektabilitas pada pasien karsinoma pankreas dilihat dari analisa kurva ROC didapatkan area under ROC curve data sebesar 83,8\% (CI 95\%: 54,4\% - 100\%). Pada tabel kurva ROC, kemampuan CA 19-9 dalam memprediksi unresektabilitas pada pasien karsinoma pankreas memiliki cut off point 126,76 U/dl dengan sensitifitas CA 19-9 sebesar 76,9\% dan spesifisitas CA 19-9 sebesar 80\%. Secara akademis, penelitian ini dapat memberikan sumbangsih berupa data untuk penelitian dalam mencari faktor-faktor risiko prognostik pasien karsinoma pankreas maupun manajemen penatalaksanaan operasi pada pasien karsinoma pankreas. 


\section{DAFTAR PUSTAKA}

1. Buchler,Uhl,Malfertheiner, Sarr. Disease of the Pancreas. Karger 2004

2. McCulloch, Peter et all. Gastrointestinal Oncology Evidence and Analysis. Informa. 2005.10;232

3. Mehmet Killic et all. Value of Preoperatif Serum CA 19-9 levels in predicting resectability of pancreatic cancer. Can J surg. 2006: 9 (4): 241 245.

4. Lall CG, Howard TJ, Skandarajah A, et al. New concepts in staging and treatment of locally advanced pancreatic head cancer. AJR Am J Roentgenol. 2007;189:1044-1050. doi: 10.2214/ AJR.07.2131

5. Vogt DP. Pancreatic cancer: a current overview. Curr Surg 2000; 57:214-20.

6. American Cancer Society. Tumor Markers. 2012. [Available at http://www.cancer.gov. Accessed on June 10 ${ }^{\text {th }}$ 2016]

7. National Cancer Institute. Tumor markers. 2012. [Available at http://www.cancer.gov. Accessed on June $5^{\text {th }}$ 2016]

8. Rückert F, Pilarsky C, Grützmann R. Serum Tumor Markers in Pancreatic Cancer - Recent Discoveries. Cancers. 2010: 2: 1107-24

9. Ballehaninna UK, Chamberlain RS. The Clinical Utility of serum CA 19-9 gin the diagnosis, prognosis and management of Pancreatic Adenocarcinoma: J Gastrointest Oncol 2012; 3(2):105-19.
10. Sudoyo AW, Setiyohadi B, Alwi I, dkk. Ed. Buku Ajar Ilmu Penyakit Dalam. Ed 4. Pusat Penerbitan Ilmu Penyakit. Dalam FK UI. Jakarta; 2006

11. Dahlan, M. Sopiyudin. 2009. Besar Sampel dan Cara Pengambilan Sampel dalam Penelitian Kedokteran dan Kesehatan. Jakarta : Salemba Medika

12. Suresh T. Chari, MD. Semin Oncol. 2007: 34(4); 284-294.

13. Locker G Y, Hamilton S, et al. ASCO 2006 Update of recomendation for The Usa of Tumor Markers in Gastrointestinal Cancer. JCO 2006; 24: 5313-27.

14. Kannagi Reiji, Carbohydrate Antigen Sialyl Lewis a - Its Pathophysiologycal Significance and Induction in Cancer prograssion. Chang Gung Med J. 2007; 3: 189-207.

15. Hardjoeno H, dkk. Tumor Marker. Interpretasi Hasil tes Laboratorium Diagnostik, bagian dari standar pelayanan medik. Makassar: Lephas. 2012: 422

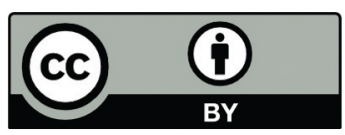

This work is licensed under a Creative Commons Attribution 